\title{
Acute Osteomyelitis After Varicella Infection in an Infant: A Case Report*
}

\author{
Süt Çocuğunda Suçiçeği Sonrasında Gelişen \\ Akut Osteomiyelit: Olgu Sunumu
}

\author{
Murat Sütçü', Yasin Yılmaz', Nuran Salman', Güntulu Duran Şık², Fuat Bilgili³, Bülent Oğuz Erol', \\ Agop Çıtak ${ }^{2}$, Ayper Somer ${ }^{1}$ \\ ' Department of Pediatric Infectious and Clinical Immunology, Istabul University Istanbul School of Medicine, Istanbul, Turkey \\ ${ }^{2}$ Division of Pediatric Insentive Care, Istabul University Istanbul School of Medicine, Istanbul, Turkey \\ ${ }^{3}$ Department of Orthopedics, Istabul University Istanbul School of Medicine, Istanbul, Turkey \\ ${ }^{4}$ Department of Radiology, Istabul University Istanbul School of Medicine, Istanbul, Turkey
}

* This case was presented as a poster in "32 ${ }^{\text {nd }}$ Annual Meeting of the European Society for Pediatric Infectious Diseases (ESPID2014) (Dublin, Ireland)".

\section{Abstract}

Varicella infections in infants are commonly self-limited disease but sometimes can cause severe complications and also result in death. The varicella vaccine is highly effective in preventing severe varicella and has significantly decreased varicella incidence, hospitalizations, and deaths. The most common complications of Varicella infection that require hospitalization are skin/soft tissue infections, bone/joint infections, sepsis, pneumonia, thrombocytopenia and dehydration. Here we report, a ten-month-old female infant hospitalized for varicella sepsis and purpura fulminans. In the first month of her treatment, osteomyelitis of left elbow has occurred and operated and treated successfully. Osteomyelitis should always be considered in any child who develops pain, swelling and limitation of movement in a limb during or after varicella infection.

Keywords: Varicella zoster infection, osteomyelitis, infant
Özet

Süt çocuklarında suçiçeği enfeksiyonu genellikle kendini sınırlayan bir hastalıktır. Nadiren ciddi komplikasyonlara yol açarak ölüme neden olabilir. Hastaneye yatış gerektiren komplikasyonlar arasında deriyumuşak doku enfeksiyonları, kemik-eklem enfeksiyonları, sepsis, pnömoni, trombositopeni ve dehidratasyon en çok saptananlardır. Suçiçeği aşısı, şiddetli suçiçeğinin önlenmesinde son derece etkili olup Amerika u çiçeği sıklığını, hastaneye yatış ve mortaliteyi anlamlı düzeyde azaltmıştır. Burada, suçiçeği enfeksiyonuna bağlı sepsis ve purpura fulminans gelişen on aylık kız hasta sunuldu. Hastane yatışının birinci ayında sol dirsekte ağrı, şişlik ve hareket kısıtlılığı saptanan hastaya osteomiyelit tanısı konularak başarı ile tedavi edildi.

Anahtar Kelimeler: Suçiçeği, osteomyelit, süt çocuğu 


\section{Introduction}

Varicella zoster infections, also known as chickenpox, is a highly contagious disease caused by the varicella zoster virus (VZV). VZV causes a systemic infection that provides lifelong immunity which transmitted from person to person by direct contact and/or inhalation of aerosols from infected respiratory tract secretions (1). Nevertheless, severe complications can occur even in previously healthy children, including secondary bacterial infections. Hospitalization of patients with varicella is most commonly due to complications. The most commonly encountered complications of varicella that require hospitalization are neurologic, respiratory, hematological, secondary bacterial infection ( $\mathrm{skin} / \mathrm{soft}$ tissue infections, bone/joint infections, sepsis, pneumonia) and other complications (dehydration) (2).

Here we report, a ten-month-old female infant hospitalized for varicella sepsis and purpura fulminans. Then osteomyelitis of left elbow has been detected.

\section{Case Report}

A 10-month-old girl with a 4-day history of varicella rash (scalp, face, neck, body and all extremites) was admitted to family medicine. Symptomatic treatment was prescribed, but after vomiting and diarrhea has occurred, she was admitted to state hospital. With deterioration of consciousness, patient was transferred our Pediatric Intensive Care Unit. Physical examination showed respiratory distress, hypotension, tachycardia and high fever. The patient on admission had a leukocyte count of $3.440 \mu \mathrm{l}$, C-reactive protein of $150 \mathrm{mg} /$ $\mathrm{dL}$, thrombocyte count of $45.000 \mu \mathrm{l}$. Patient was defined as in sepsis secondary to chickenpox and was intubated due to respiratory distress. Bleeding from nose and mouth was met by thrombocyte and erythrocyte suspensions. Elevation of D-dimer $35.6 \mathrm{~g} / \mathrm{mL}$ (normal < 0.5), blood fibrinogen 50.1 $\mathrm{g} / \mathrm{ml}$ (normal 150-400) and a decrease in the erythrocyte sedimentation rate $(8 \mathrm{~mm} / \mathrm{h})$ suggested that this case was complicated with disseminated intravascular coagulation. Plasmapheresis was administered due to severe sepsis, coagulopathy and multiple organ failure. As infection markers elevated, ceftriaxone was replaced with teicoplanin and meropenem. Soft tissue necrosis and hemorrhages on distal extremities defined ecchymoses and petechiae with consolidated irregular areas of blue-black hemorrhagic necrosis and a surrounding erythematous border ,purpura fulminans, were dressed daily. Two weeks later, pulmonary hemorrhage developed and thrombocyte and erythrocyte suspensions were applied (thrombocyte count of $30.000 \mu \mathrm{l}$ ), (Figures 1,2). One month following admission to hospital, limb pain, swelling and movement restriction of left elbow of infant were realized and conventional X-Ray showed joint destruction of the elbow affecting the metaphyseal bone of distal humerus and common periosteal reaction. Magnetic resonance imaging(MRI) of the elbow revealed massive inflammation of the joint, prominent periosteal thickening around humerus, radius distal metaphysic and epiphytic edema with involvement of the surrounding muscle groups (Figures 3,4). These findings were consistent with osteomyelitis and patient was operated by orthopedic physician. Intraoperatively, massive necrotic debris and seropurulent fluid were found around the periosteum of humerus and removed. Arthrocentesis from elbow showed abundant polymorph nuclear leucocytes and cultures were negative. Intravenous treatment with teicoplanin was started and continued for 2 weeks. One week following the surgery, X-Ray examinations showed severe periosteal reaction and physiotherapy was performed for patient. Patient was discharged and oral clindamycin was given for a further two months. And X-ray of left elbow showed no further radiological findings and recovery was proved.

\section{Discussion}

Chickenpox, caused by the VZV, is a common highly infectious selflimiting eruptive disease of childhood. Although it is a benign disease in children, it can sometimes develop into a more serious illness. After introduction of varicella vaccination program in 1995 in United States, the incidence of varicella declined by $80-90 \%$ in all age groups (3). In Turkey, routine vaccination against varicella has been administrated since 2012; therefore information on change of varicella incidence is currently not available. The common complications of varicella in children requiring hospitalization are pulmonary, gastrointestinal, skin and neurological

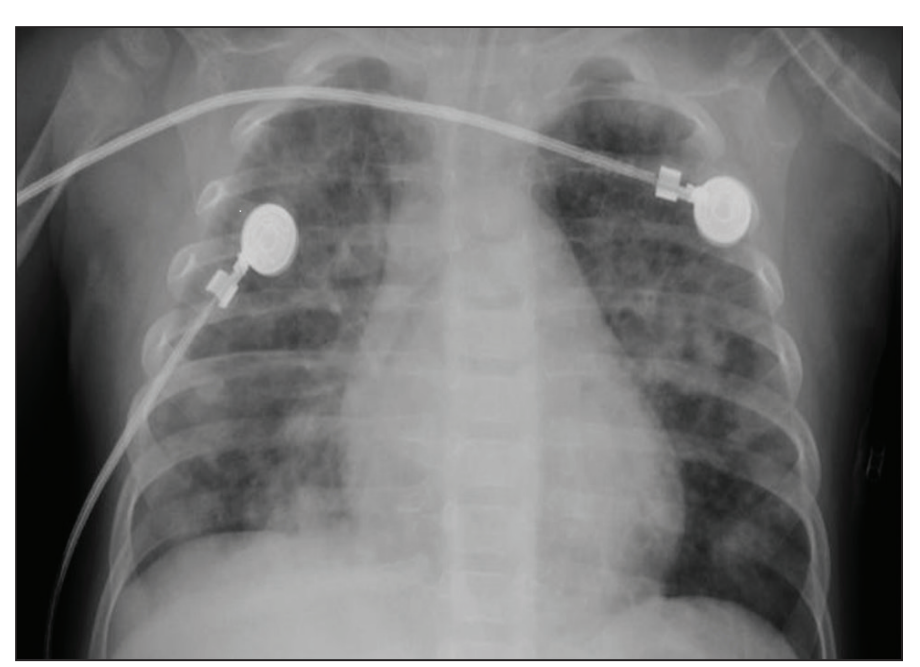

Figure 1. Pulmonary hemorrhage seen on chest X-ray. 


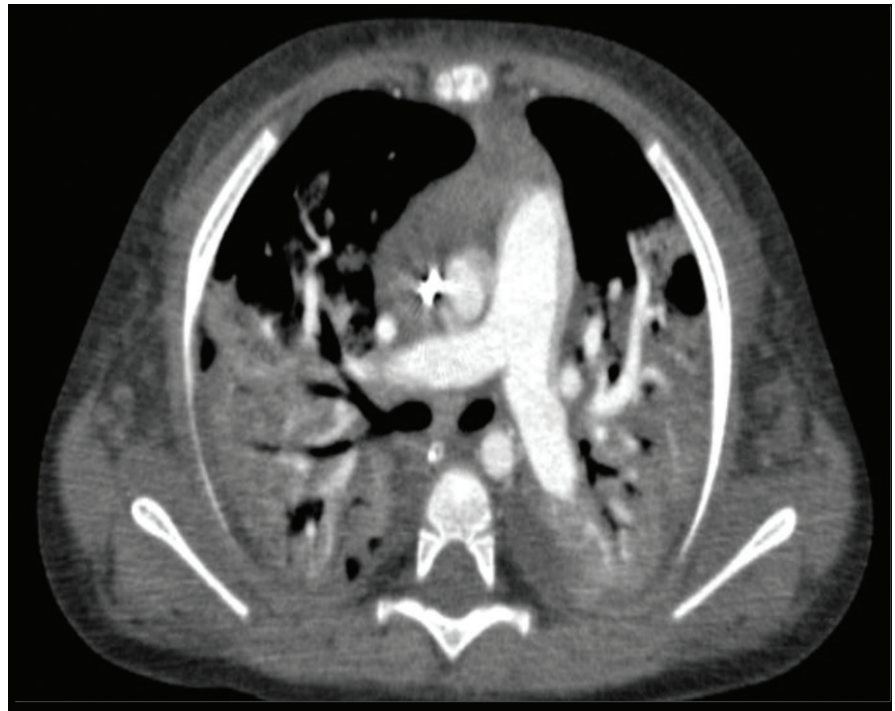

Figure 2. Pulmonary hemorrhage seen on thorax computerized tomography (CT).

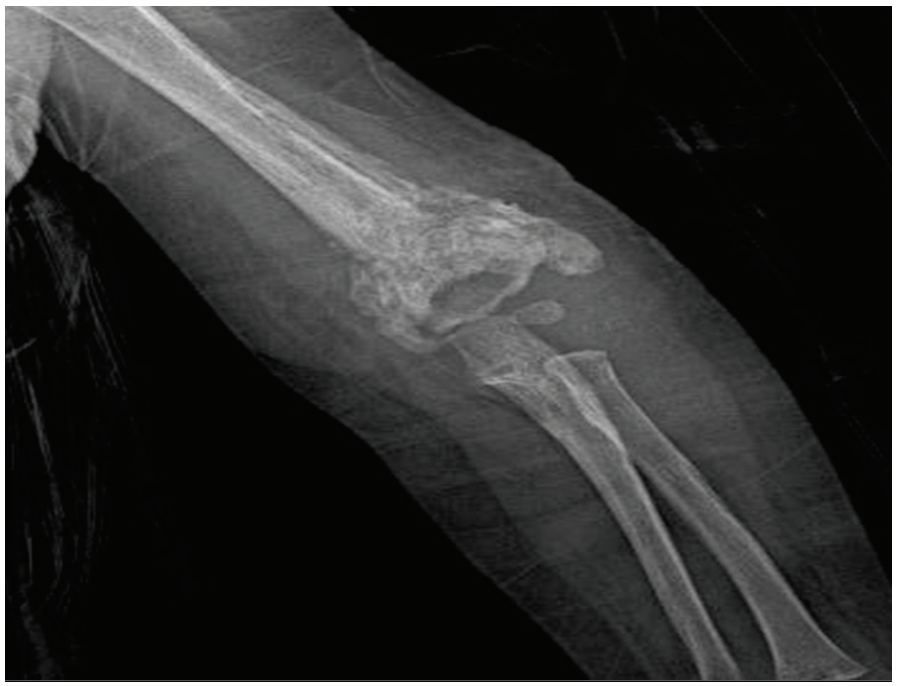

Figure 3. Periosteal reaction described in osteomyelitis seen on direct X-Ray.

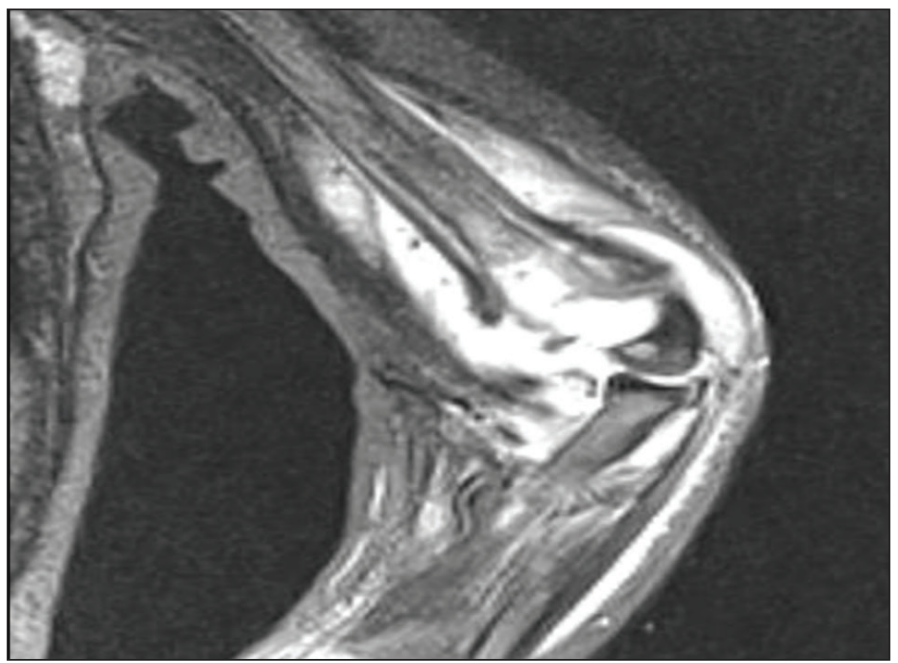

Figure 4. Periosteal reaction described in osteomyelitis seen on magnetic resonance imaging (MRI). complications. Infrequently reported potential complications included thrombocytopenia, sepsis and bone/joint infections (2). Our case had had almost all type of complications reported above. Initially patient had suffered from secondary bacterial pneumonia but during follow up acute respiratory distress syndrome and pulmonary hemorrhage had developed (Figures 1,2). The multiple organ failure and sepsis had occurred in patient that had thrombocytopenia.

Purpura fulminans is the cutaneous manifestation of disseminated intravascular coagulation and results in microvascular thrombosis together with hemorrhagic skin and soft tissue necrosis (8). In our case, soft tissue necrosis and hemorrhages on extremities defined as purpura fulminans were dressed daily. The necrosis may extend to the muscle and the bone, contributing to a late mortality and morbidity. Its healing leads to scarring, and auto-amputation of the digits.

Musculoskeletal complications were rare complications of hospitalization. In one study with 417 admissions for varicella related complications, $6 \%$ were for musculoskeletal complications (4). Inflammation of the bone can occur either directly or via the blood at osteomyelitis (5). Staphylococcus aureus and Group A beta-hemolytic streptococcus are the most common bacterial pathogens responsible for osteomyelitis $(4,6)$, although gram negative bacteria, Kingella kingae, is emerging cause (7). Group A streptecoccus have been reported to occur frequently after chickenpox, presumably because of breaks in the skin or impaired host response. In our case, the microbiological culture was negative as it might be due to antibiotics that were administered early in care. Clinical suspicion should be kept in mind with swelling, pain, redness and limitation of movement of a limb in a patient with varicella. Conventional X-Ray, ultrasound and MRI are useful to detect the presence of osteomyelitis and for the differential diagnosis (Figures 3,4). Treatment of acute osteomyelitis is traditionally 4-6 weeks of appropriate antimicrobial therapy along with surgical intervention if needed. In our case, intravenous antibiotics were administered against osteomyelitis for two weeks and carried on with oral antibiotics for two months. Clindamycin is an antimicrobial agent widely used for the treatment of bone and joint infections because of its activity against staphylococci, streptococci and anaerobic bacteria. In addition, clindamycin has high levels of joint and bone penetration and inhibits biofilm formation and bacterial adherence (9).

In this report, we have presented an infant with multiple complications of varicella infection. Although varicella vaccination program was introduced recently in Turkey, varicella infections still should be paid attention in infants in terms of complications. 
Informed Consent: Written informed consent was obtained from parent of patient.

Peer-review: Externally peer-reviewed.

Author Contributions: Concept - MS; Design - MS, YY; Supervision - NS, AÇ, AS; Collection and/or Processing - YY, GDŞ; Analysis and/ or Interpretation - FB, OBE; Literature Review - MS, YY; Writing - MS; Critical Review - NS, AS

Conflict of Interest: The authors have not reported a conflict of interest.

Financial Disclosure: The authors declared that they did not receive financial support.

\section{References}

1. Marin M, Güris D, Chaves SS, et al; Advisory Committee on Immunization Practices, Centers for Disease Control and Prevention (CDC). Prevention of varicella: recommendations of the Advisory Committee on Immunization Practices (ACIP). MMWR Recomm Rep 2007;56:1-40. [CrossRef]

2. Galil K, Brown C, Lin F, Seward J. Hospitalizations for varicella in the United States, 1988 to 1999. Pediatr Infect Dis J 2002;21:931-5. [CrossRef]

3. Seward JF, Watson BM, Peterson $C L$, et al. Varicella disease after introduction of varicella vaccine in the United States, 1995-2000. JAMA 2002;287:606-11. [CrossRef]
4. Schreck P, Schreck P, Bradley J, Chambers H. Musculoskeletal complications of varicella. J Bone Joint Surg Am 1996;78:1713-9. [CrossRef]

5. Nade S. Acute haematogenous osteomyelitis in infancy and childhood. J Bone Joint Surg 1983;65:109-19. [CrossRef]

6. Chen WL, Chang WN, Chen YS, et al. Acute community-acquired osteoarticular infections in children: high incidence of concomitant bone and joint involvement. J Microbiol Immunol Infect 2010;43:332-8. [CrossRef]

7. Ceroni $D$, Cherkaoui A, Ferey $S$, et al. Kingella kingae osteoarticular infections in young children: clinical features and contribution of a new specific real-time PCR assay to the diagnosis. J Pediatr Orthop 2010;30:301-4. [CrossRef]

8. Karadag AS, Bilgili SG, Calka O, Ceçen I, Akbayram S. A case of fulminant varicella infection with purpura fulminans, hepatitis, and rhabdomyolysis. Indian J Dermatol 2012;57:503. [CrossRef]

9. Lazzarini L, Lipsky BA, Mader JT. Antibiotic treatment of osteomyelitis: what have we learned from 30 years of clinical trials? Int J Infect Dis 2005;9:127-38. [CrossRef] 